\title{
Profile of Catfish (Clarias sp) Oocyte Exposed by Laserpuncture
}

\author{
Dyah Hariani (Corresponding author) \\ Doctoral Program, Faculty of Fisheries and Marine Sciences \\ University of Brawijaya, Malang-Indonesia \\ Biology Department, FMIPA, State University Surabaya, Surabaya-Indonesia \\ E-mail: dyahhariani@yahoo.com
}

Marhendra A. P. W

Biology Department, FMIPA, University of Brawijaya, Malang-Indonesia

Aulanni Am

Chemistry Department, FMIPA, University of Brawijaya, Malang-Indonesia

\section{Suprayitno E}

Faculty of Fisheries and Marine Sciences, University of Brawijaya, Malang-Indonesia

Received: May 6, 2014 Accepted: May 19, 2014

doi:10.5296/jbls.v5i2.5585 URL: http://dx.doi.org/10.5296/jbls.v5i2.5585

\begin{abstract}
An exposure of low-powered laserpuncture at reproductive acupoint of catfish brood stock is known stimulate oocyte maturation. However, the profile of oocyte resulted from laserpuncture exposure has not been known. The present study aimed to identify the profile of catfish (Clarias sp.) oocyte in post-exposure laserpuncture. A total of 48 catfishes with ages of 8-9 months was grouped into two, i.e. fishes were exposed with laserpuncture and without exposure to laserpuncture (control) with 3 replications. Laserpuncture exposure was conducted once a week until the brood stock matured. Profile of oocyte such as, the GSI value, egg diameter, total of oocytes and the gonad maturity stage were examined. The results showed that
\end{abstract}


laserpuncture exposure at the catfish reproductive acupoint could trigger the oocyte development without reducing quality of the oocyte indicated by the increase of gonadosomatic index (GSI), oocyte diameter, total of oocytes and gonad maturity stage similar to control. Moreover, laserpuncture exposure accelerated the gonad maturation, three weeks faster than control.

Keywords: Laserpuncture exposure, Oocyte diameter, Total of oocytes, GSI, Gonad maturity stage

\section{Introduction}

Oocyte development is naturally regulated by gonadotropin hormone $(\mathrm{GtH})$ which is produced by pituitary hypothalamic as a response to environmental signals (Nagahama, 1994; Cornish, 1998; Bhattacharya, 1999; Wijayanti et al., 2009; Ramezani-Fard et al., 2012; Pandey, 2013). Nevertheless, natural oocyte development, in order to reach the oocyte maturation, requires longer time than manipulating the environment by the use of hormone, feed supplementation (Solang and Lamondo, 2009), and low powered laserpuncture exposure (Kusuma et al., 2008).

Laserpuncture exposure on living organisms, such as catfish, with low power (4-5 mW) (Sukarto, 1992) alters the cell membrane potential and stimulates hormone production (Karu, 1988; Koutna et al., 2003; Katona et al., 2004; Gao and Da Xing, 2009; Kusuma et al., 2012b). Moreover, laserpuncture exposure at the reproductive acupoint for 15 seconds increases the gonadotropin hormone (GtH) production (Kusuma et al., 2012b; Kusuma, 2013), which is the regulator for steroidogenesis, oogenesis, and oocyte maturation in catfish (Jalabert, 2008).

Laserpuncture induces maturation of the oocytes, ovulation and spawning (Kusuma and Hariani, 2008; Hariani and Kusuma, 2009; Hariani et al., 2010) and enlarges the GtH dynamics (Kusuma et al., 2012a; Kusuma et al., 2012b; Kusuma, 2013). Although the low power- ed laserpunceture proves the stimulation of $\mathrm{GtH}$ production and oocyte maturation, its effect on Gonado Somatic Index (GSI), oocyte diameter, total of oocytes, and gonad maturity stage of female catfish has not yet been studied. Fish gonad development is followed by an increase of diameter and total of oocytes (Lucey, 2009; Konan et al., 2014) and can be determined by GSI value (Poompoung et al., 2012). Therefore, we have examined profile of catfish oocyte after exposed by laserpuncture.

\section{Materials and Methods}

\subsection{Experimental Conditions}

This study was carried out in Freshwater Aquaculture Management Unit (UPBAT) Kepanjen; Biochemistry Laboratory, Faculty of Medicine, Brawijaya University; and Clinical Pathology Laboratory of dr. Soetomo Hospital, Surabaya; from January to May 2012. We collected 8-9 month old of F1 catfish brood- stock of cross-breed from female Sangkuriang and male Paiton. A total of 48 females with 760-1300 g of body weight and 48 males with 1140-1759 g of body weight were obtained from one population in UPBAT. All catfish had been acclimated for seven days in $2 \times 2 \times 1 \mathrm{~m}^{3}$ in tarpaulin ponds, fed in morning and afternoon with $36 \%$ protein (Pokphan 781-3; CP Prima production). After acclimation, the mature gonad male and female catfish (ratiol:1) were transported to spawning pond facilitated with 


\section{Ml Macrothink}

kaka-ban for spawning. The following day, after the catfish had been spawned (assuming that they had no mature oocyte), the female catfish were treated by laserpuncture (soft laser Helium-Neon (He-Ne); $5 \mathrm{~mW}$ and $\lambda 632.8 \mathrm{~nm}$ ) for 15 seconds at the reproductive acupoint ( $2 / 3$ of the ventral body) for once a week until gonads matured (three weeks) (Kusuma et al., 2007).

\subsection{GSI, Total Oocyte and Oocyte Diameter Measurement}

The catfish were weighed before (W) and after removing their gonad (GW) to obtain GSI value by the formula: $\mathrm{GSI}=(\mathrm{GW} /(\mathrm{W}-\mathrm{GW}))^{* 100}$ (Rocha, 2008). The oocyte diameter was measured by using an ocular micrometer under the light microscope (Olympus CX 4) (Foucher and Beamish, 1980). Total oocytes were counted as follow $0.03 \mathrm{~g}$ of oocytes (GS) were accounted, to obtain a number of oocytes (n), and then total oocytes/broodstock were counted based on a formula $\mathrm{N}=(\mathrm{GW} / \mathrm{GS}) * \mathrm{n}$ (Ayidin and Sahin, 2011).

\subsection{Gonad Maturity Stage Determination}

Gonad maturity stage was determined by Hematoxylin and Eosin staining based on McDowell and Trump (1976) with slight modification. The upper part of the gonad (3 cm long) was fixed by PFA $10 \%$ and dehydrated in alcohol series. Then, it was continued by clearing with xylol and embedding in the paraffin block. The preparation was cutted by a microtome (with thickness $4-5 \mu \mathrm{m}$ ) and then stained by Hematoxylin and Eosin. Next, it was mounted in Canada balsam and observed under a light microscope (Olympus CX 4) (Santos et al., 2005). The determination of gonad maturity stage refers to Çek and Yilmaz (2007).

\section{Results and Discussion}

This result showed that the laserpuncture accelerated gonad maturation in week four; this was indicated by the brownish red to blackish purple of the pores genitals. The ovary was dominated by oocytes in stage V and VI (Table 1), GSI was 15.52 \pm 0.73 (Table 4), oocyte diameter was $1.227 \pm 0.031 \mathrm{~mm}$ (Table 2), and the total of oocyte was $159885 \pm 20577$ (Table $3)$. On the contrary, the control group showed that the gonad was mature in week seven. The ovary was dominated by oocytes in stage V and VI (Table 1), GSI was 16.39 \pm 1.23 (Table 4), oocyte diameter was $1.267 \pm 0.058 \mathrm{~mm}$ (Table 2), and the total of oocytes was $144150 \pm 49441$ (Table 3). Laserpuncture exposure was confirmed to be able to accelerate the gonad maturity in three weeks faster than that of the control group without reduce the oocyte quality.

Table 1. Total of oocytes development stages after laserpuncture exposed compared to the control group

\begin{tabular}{|c|c|c|c|c|c|c|c|c|c|c|c|c|}
\hline \multirow{3}{*}{ Week } & \multicolumn{12}{|c|}{ Oocyte developmental stage (Çek and Yilmaz, 2007) } \\
\hline & \multicolumn{2}{|c|}{ I } & \multicolumn{2}{|c|}{ II } & \multicolumn{2}{|c|}{ III } & \multicolumn{2}{|c|}{ IV } & \multicolumn{2}{|c|}{ V } & \multicolumn{2}{|c|}{ VI } \\
\hline & $\mathrm{C}$ & $\mathrm{L}$ & $\mathrm{C}$ & $\mathrm{L}$ & $\mathrm{C}$ & $\mathrm{L}$ & $\mathrm{C}$ & $\mathrm{L}$ & $\mathrm{C}$ & $\mathrm{L}$ & $\mathrm{C}$ & $\mathrm{L}$ \\
\hline 0 & $4 \pm 1$ & $4 \pm 1$ & $3 \pm 0$ & $3 \pm 0$ & $2 \pm 0$ & $2 \pm 0$ & $1 \pm 0$ & $1 \pm 0$ & $1 \pm 0$ & $1 \pm 0$ & $1 \pm 0$ & $1 \pm 0$ \\
\hline 1 & $6 \pm 1$ & $6 \pm 0$ & $3 \pm 1$ & $8 \pm 1$ & $4 \pm 0$ & $6 \pm 2$ & $2 \pm 0$ & $7 \pm 2$ & $2 \pm 0$ & $5 \pm 1$ & $2 \pm 0$ & \\
\hline 2 & $4 \pm 1$ & $6 \pm 2$ & $5 \pm 1$ & $7 \pm 1.7$ & $4 \pm 1$ & $6 \pm 1$ & $2 \pm 0$ & $9 \pm 1.7$ & $2 \pm 0$ & $6 \pm 1$ & $2 \pm 0$ & $7 \pm 2$ \\
\hline 3 & $7 \pm 1$ & $7 \pm 2$ & $6 \pm 2.7$ & $7 \pm 2.7$ & $4 \pm 1$ & $6 \pm 0$ & $8 \pm 1.7$ & $6 \pm 2$ & $3 \pm 1.7$ & $8 \pm 2$ & $2 \pm 1$ & $7 \pm 1$ \\
\hline 4 & $8 \pm 2$ & $13 \pm 2$ & $9 \pm 1.7$ & $15 \pm 2$ & $10 \pm 1.7$ & $15 \pm 2$ & $6 \pm 1.7$ & $13 \pm 2.7$ & $4 \pm 1$ & $13 \pm 2.7$ & $2 \pm 0$ & $10 \pm 1.7$ \\
\hline
\end{tabular}




\begin{tabular}{|c|c|c|c|c|c|c|c|c|c|c|c|c|}
\hline 5 & $10 \pm 2.7$ & - & $8 \pm 1$ & - & $6 \pm 1.7$ & - & $4 \pm 1.7$ & - & $3 \pm 1$ & - & $2 \pm 0$ & - \\
\hline 6 & $13 \pm 1.7$ & - & $10 \pm 2$ & - & $12 \pm 2.7$ & - & $6 \pm 1.7$ & - & $4 \pm 1.7$ & - & $3 \pm 1$ & - \\
\hline 7 & & - & & - & $11 \pm 2$ & - & $10 \pm 1.7$ & - & $8 \pm 1.7$ & - & $6 \pm 1.7$ & - \\
\hline
\end{tabular}

Notes: $\mathrm{C}=$ number of oocytes without laserpuncture exposure (control)

$\mathrm{L}=$ number of oocyte after laserpuncture exposure

$=$ not observed, broodstock already in mature gonad

Table 2. Oocyte diameter after laserpuncture exposed compared to control group:

\begin{tabular}{|c|l|l|}
\hline Week & Laserpuncture exposed group $(\mathrm{mm})$ & Control group $(\mathrm{mm})$ \\
\hline 0 & $0.943 \pm 0.025$ & $0.943 \pm 0.025$ \\
\hline 1 & $1.027 \pm 0.042$ & $0.97 \pm 0.027$ \\
\hline 2 & $1.057 \pm 0.049$ & $0.993 \pm 0.012$ \\
\hline 3 & $1.067 \pm 0.058$ & $1.057 \pm 0.060$ \\
\hline 4 & $1.227 \pm 0.031^{*}$ & $1.093 \pm 0.012$ \\
\hline 5 & - & $1.163 \pm 0.025$ \\
\hline 6 & - & $1.193 \pm 0.012$ \\
\hline 7 & - & $1.267 \pm 0.058 *$ \\
\hline
\end{tabular}

Notes: ${ }^{*}$ : oocytes were mature, indicated by brownish yellow and observation was terminated

Table 3. Total oocytes after laserpuncture exposed compared to control group:

\begin{tabular}{|c|l|l|}
\hline Week & Laserpuncture exposed group (eggs/ broodstock) & Control group (eggs/broodstock) \\
\hline 0 & $15553 \pm 2771$ & $15553 \pm 2771$ \\
\hline 1 & $45633 \pm 1348$ & $29125 \pm 7278$ \\
\hline 2 & $138693 \pm 1205$ & $103368 \pm 18903$ \\
\hline 3 & $158402 \pm 44058$ & $110952 \pm 30265$ \\
\hline 4 & $159885 \pm 20577 *$ & $117212 \pm 47342$ \\
\hline 5 & - & $122254 \pm 26947$ \\
\hline 6 & - & $127349 \pm 17690$ \\
\hline 7 & - & $144150 \pm 49441^{*}$ \\
\hline
\end{tabular}

Notes: *: oocytes were mature, indicated by brownish yellow and observation was terminated

Table 4. GSI after laserpuncture exposed compared to control group

\begin{tabular}{|c|l|l|}
\hline Week & Laserpuncture exposed group & Control group \\
\hline 0 & $2.43 \pm 0.78$ & $2.43 \pm 0.78$ \\
\hline 1 & $5.00 \pm 0.339$ & $4.19 \pm 0.199$ \\
\hline 2 & $13.46 \pm 0.311$ & $10.98 \pm 1.019$ \\
\hline 3 & $14.44 \pm 3.062^{*}$ & $12.12 \pm 2.636$ \\
\hline 4 & $15.52 \pm 0.728^{* *}$ & $1348 \pm 3.061$ \\
\hline 5 & - & $14.73 \pm 1.146$ \\
\hline 6 & - & $15.90 \pm 4.490^{*}$ \\
\hline 7 & - & $16.385 \pm 1.237^{* *}$ \\
\hline
\end{tabular}

Notes: brownish red in porous genitals and small oocytes were separated individually

${ }^{* *}$ : oocytes were mature, indicated by brownish red to blackish purple in porous genitals and large oocytes were separated individually and observation was terminated

The enlargement of oocyte diameter was due to the oocyte cytoplasm filled with yolk mass. Yaron (1995) points out that in vitellogenesis level, both number and size of yolk granule are escalated; thus, it results in a bigger oocyte volume and higher gonad weight.

Laserpuncture accelerated gonad maturation three weeks faster than control (Table 1) and GSI 
enhancement in catfish (Clarias sp) (Table 4). This data corroborates Kusuma et al. (2012b); Kusuma (2013) described that laserpuncture exposure at the reproductive acupoints increased $\mathrm{GtH}$ and GSI in catfish. The phenomenon suggested that laserpuncture exposure at the reproductive acupoint be an alternative method to accelerate gonad maturation without reducing the quality of oocytes profile. Therefore, the method is warrant for improving catfish reproduction and can be implemented for aquaculture catfish. Oocyte profile, i.e. oocyte size, total oocyte and GSI has increased in both laserpuncture and without exposure (Table 2,3 and 4). However, the laserpuncture exposure able to stimulate oocyte maturation faster followed by increasing oocyte diameter and GSI value compared to control. It is also suggested by Kusuma (2013) that laserpuncture exposure could significantly raise the gonadotropin hormone production, like GtH I, GtH II and the GSI.

GtH-I and GtH-II stimulate the gonadal gland to produce the steroid hormone namely $17 \beta$-estradiol. According to Arukwe and Goksøyr (2003), Berg et al. (2004), Jalabert (2005), and Muhammad et al. (2011), 17 $\beta$-estradiol stimulates hepatic cell to synthesize vitellogenins, which will be absorbed by the oocyte (Jalabert, 2005; Muhammad et al., 2011). De Vlaming et.al. (1982) also states that mature oocyte has high value of GSI in fish that is ready to spawn. Konan (2014) explained that GSI is required to assess gonad activities and development.

GtH II stimulates the process of oocyte in the final maturation by Maturation Inducing Hormone (MIH) (Nagahama, 1994) resulting upregulation of the Maturation Promoting Factor (MPF). Then, the MPF (Nagahama, 1994; Yaron et al., 2003) stimulates the Germinal Vesicle Break Down (GVBD) so that the mature oocytes will soon be ovulated, and spawning occurs (Clelland and Peng, 2009). Therefore, the data indicated that laserpuncture exposure could accelerate the oocyte developmental stage, and shorten the spawning time (Kusuma, 2013).

\section{Conclusion}

Laserpuncture-exposed catfish has gonad maturation in week-four indicated by oocyte diameter $1.227 \pm 0.031 \mathrm{~mm}$, total of oocytes $159885 \pm 20577 \mathrm{eggs} /$ broodstock, GSI $15.52 \pm 0.73$. Laserpuncture accelerated gonad maturation three weeks faster than control of catfish without reducing the oocyte quality.

\section{Acknowledgement}

We would like to thank to the Head of Fisheries and Marine Services of East Java Province, who granted permission to conduct this research in UPBAT Kepanjen, and Mr. Wibi Riawan (Biochemistry Laboratory, Faculty of Medicine, Brawijaya University, Malang) for his assistance for this research.

\section{References}

Arukwe, A., \& Goksøyr, A. (2003). Review. Eggshell and egg yolk proteins in fish: hepatic proteins for the next generation: oogenetic, population, and evolutionary implications of endocrine disruption. Comparative Hepatology, 2(4), 1-21.

Aydin, I., \& Sahin, T. (2011). Reproductive performance of turbot (Psetta maxima) in the southeastern Black sea. Tur J. Zool, 35(1), 109-113. 
Berg, B., Modig, C., \& Per-Erik, O. (2004). 17ß-estradiol-induced vitellogenesis is inhibited by cortisol at the post-transcriptional level in Artic char (Salvelinus alpinus). Reproductive Biology and Endocrinology, 2(62), 1-10.

Bhattacharya, S. (1999). Recent advances in the hormonal regulation of gonadal maturation and spawning in fish. Special Section:Fisheries-Science \& Technology. Current Science, 3(3), 342-349. 10 February 1999.

Clelland, E., \& Peng, C. (2009). Endocrine/paracrine control of zebrafish ovarian development. Molecular and Cellular Endocrinology, 312, 42-52. http://dx.doi.org/10.1016/j.mce.2009.04.009

Cornish, D. A. (1998). Seasonal steroid hormones profiles in plasma and gonads of the tilapia, Oreochromis mossambicus. Water SA., 24(3), 257-363. July 1998.

De Vlaming, V., Grossman, G., \& Chapman, F. (1982). On the use of the gonadosomatic index. Comp. Biochem. Physiol, 73A, 31-39. http://dx.doi.org/10.1016/0300-9629(82)90088-3

Foucher, R. P., \& Beamish, R. J. (1980). Production of nonviable oocyte by production of Pacific hake (Merluccius productus). Canadian Journal of Aquatic Science, 37, 41-48. http://dx.doi.org/10.1139/f80-004

Gao, X., \& Da Xing. (2009). Review Open Access. Molecular mechanisms of cell proliferation induced by low power laser irradiation. Bio Med Central. Journal of Biomedical Science, 16, 4. http://dx.doi.org/10.1186/1423-0127-16-4

Hariani, D., \& Kusuma, P. S. W. (2009). Biostimuli reproduksi ikan lele Dumbo betina dengan penembakan laserpunktur. Jurnal Berkala Penelitian Hayati. PBI Cabang Jawa Timur. Edisi Khusus, 3D, 79-83. 01 December 2009.

Hariani, D., Kusuma, P. S. W., \& Widodo, M. S. (2010). Pemberdayaan kelompok pembenih lele untuk peningkatan produksi benih menggunakan laserpunktur sebagai upaya peningkatan pendapatan di Desa Krecek, Kecamatan Pare, Kabupaten Kediri. Jurnal Aksi, 12(2),80-88.

Jalabert, B. (2005). Particularities of reproduction and oogenesis in teleost fish compared to mammals. Reprod. Nutr. Dev, 45, 261-279. http://dx.doi.org/10.1051/rnd:2005019

Jalabert, B. (2008). An overview of 30 years of international research in some selected fields of the Reproductive Physiology of Fish. Cybium, 32(2), 7-13.

Karu, T. I. (1988). Molecular mechanism of the therapeutic effect of low-intensity laser radiation. Laser in the Life Science, 2(1), 53-74.

Katona, E., Katona, G., Doaga, I. O., Seremet, T., Dumitrescu, M., Radesi, S., Matei, R., Horvath, J., Tanos, E., \& Katona, L. (2004). Membrane effects of low level infrared laser irradiation, as seen in metabolically intact and impaired human blood cells. Romanian. $J$. Biophys, 14(1-4), 99-108.

Konan, Y. A., Kone, T., Bamba, M., \& Kone, I. (2014). Reproductive strategies of the catfish Clarias buettikoferi (Pisces, Claridae) in the Tanoe-Eby Swamp Forest (South-Eastern Cöte 
d'Ivoire). World Journal of Fish and Marine Sciences, 6(1), 16-23.

Koutna, M., Janisch, R., \& Veselska, R. (2003). Effects of low-power laser irradiation on cell proliferation. Scripta Medica (BRNO), 76(3), 163-172. June 2003.

Kusuma, P. S. W. (2013). Mekanisme pelepasan hormone gonadotropin ikan lele (Clarias sp) setelah dipapar laserpunktur pada titik reproduksi. Disertasi. Pascasarjana Fakultas Perikanan dan Ilmu Kelautan. Universitas Brawijaya, Malang.

Kusuma, P. S. W., \& Hariani, D. (2008). Teknologi laserpunktur untuk mempercepat pematangan gonad ikan lele Dumbo. J Penelitian Matematika dan Sains FMIPA-UNESA, 15(2), 124-127. December 2008.

Kusuma, P. S. W., Hariani, D., Mukti, A. T., \& Satyantini W. A. (2008). Penyediaan broodstock ikan lele dumbo (Clarias gariepinus) menggunakan teknologi laserpunktur sebagai upaya penyediaan benih skala massal. Jurnal Litbang Provinsi Jawa Tengah, 6(2), 139-146. 2-December 2008.

Kusuma, P. S. W., Hariani, D., Mukti, A. T., \& Satyantini, W. A. (2007). Aplikasi teknologi laser untuk peningkatan produksi lele dalam rangka pengembangan ekonomi masyarakat desa di Kabupaten Boyolali Jawa Tengah, LP3K Kabupaten Boyolali, Boyolali.

Kusuma, P. S. W., Marhendra, A. P. M., Aulanni'am., \& Marsoedi. (2012b). Mechanism of gonadotropin hormone release in catfish (Clarias sp) upon laserpuncture exposure to reproduction acupoint. International Journal of Basic and Applied Sciences IJBAS-IJENS, 12(6), 177-182. December. 2012.

Kusuma, P. S. W., Marhendra, A. P. W., Aulanni'am., \& Marsoedi. (2012a). Mekanisme pelepasan hormon gonadotropin ikan lele (Clarias sp) setelah di induksi laserpunktur pada titik reproduksi. Seminar Nasional Tahunan IX Hasil Penelitian Perikanan dan Kelautan UGM pada Tanggal 14 July 2012.

Lucey, S. M. (2009). Characteristics of fish yolk protein and a method for inducing vitellogenin. Thesis. University of Massachusetts Amherst. September Wildlife and Fisheries Conservation.

McDowell, E. M., \& Trump, B. F. (1976). Histologic fixatives suitable for diagnostic light and electron microscopy. Arch. Pathol. Lab. Med. 100:405 in Dykstra, M.J. 1993. A Manual of Applied Techniques for Biological Electron Microscopy, Plenum Press, NY. Laboratory for Advanced Electron and Light Optical Methods College of Veterinary Medicine. 1060 William Moore Drive North Carolina State University. Raleigh, NC 27607.

Muhammad, N. A., Christianus, A., Daud, S. K., Saad, C. R., Harmin, S. A., \& Ina-Salwany, M. Y. (2011). Estrogen-Induced vitellogenin in Tor tambroides (Bleeker, 1854): Purification, characterization and elisa development. Journal of Fisheries and Aquatic Science, 6(7), 700-714. http://dx.doi.org/10.3923/jfas.2011.700.714

Nagahama, Y. (1994). Endocrine regulation of gametogenesis in fish. Int. J. Dev. Biol, 38, 217-229. 


\section{I Macrothink}

Journal of Biology and Life Science ISSN 2157-6076 2014, Vol. 5, No. 2

Pandey, A. K. (2013). Dietary and hormonal manipulations for gonadal maturation and seed production of Indian major carps and catfishes. J.Exp.Zool. India, 16(1), 19-37.

Poompoung, P., Poompuang. S., \& Kamonrat, W. (2012). Effects of warm temperatures on ovarian development of walking catfish Clarias macrocephalus (Günther, 1864) during post-spawning season. Kasetsart J. (Nat. Sci.), 46, 759-768.

Ramezani-Fard, E., Kamarudin, M. S., \& Harmin, S. A. (2012). Endocrine contol of oogenesis in teleosts. Asian Journal of Animal and Veterinary Advances.

Rocha, G. R. A. (2008). Scientific Note. The introduction of the African catfish Clarias gariepinus (Burchell, 1822) into Brazillian inland waters: a growing threat. Neotropical Ichthyology, 6(4), 693-696. http://dx.doi.org/10.1590/S1679-62252008000400020

Santos, R. N., Andrade, C. C., Santos, A. F. G. N., Santos, L. N., \& Araújo, F. G. (2005). Hystological analysis of ovarian development of the characiform Oligosarcus hepsetus (Vuvier, 1829) in Brazillian reservoir. Braz. J. Biol, 65(1), 169-177. http://dx.doi.org/10.1590/S1519-69842005000100020

Solang, M., \& Lamondo, D. (2009). Peningkatan pertumbuhan dan indeks kematangan gonad ikan nila (Oreochromis niloticus L.) melalui pemotongan sirip ekor. Torani (Jurnal Ilmu Kelautan dan Perikanan), 19(3), 143-149. December 2009.

Sukarto. (1992). Penggunaan laser untuk akupunktur. J. Acupunctur, I, 49-54.

Wijayanti, G. E., Soeminto., \& Simanjuntak, S. B. I. (2009). Profil hormon reproduksi dan gametogenesis pada gurame (Osphronemus gouramy Lac) betina. Jurnal Akuakultur Indonesia, $8(1), 77-89$.

Yaron, Z,. Gur, G., Melamed, P., Rosenfeld, H., Elizur, A., \& Levavi-Sivan, B. (2003). Regulation of fish gonadotropins. Int Rev Cytol, 3(225), 131-85. http://dx.doi.org/10.1016/S0074-7696(05)25004-0

Yaron, Z. (1995). Endocrine control of gametogenesis and spawning exposure in the carp. Aquaculture, 129, 49-73. http://dx.doi.org/10.1016/0044-8486(94)00229-H

Çek, Ş., \& Yilmaz, E. (2007). Gonad development and sex ratio of Sharptooth Catfish (Clarias gariepinus Burchell, 1822) cultured under laboratory conditions. Turk. J. Zool, 31, 35-46.

\section{Copyright Disclaimer}

Copyright for this article is retained by the author(s), with first publication rights granted to the journal.

This is an open-access article distributed under the terms and conditions of the Creative Commons Attribution license (http://creativecommons.org/licenses/by/3.0/). 